\title{
PROSES OKSIDASI BIOKIMIA UNTUK PENGOLAHAN LIMBAH SIMULASI CAIR ORGANIK RADIOAKTIF
}

\author{
GunANDJAR, ZAinus SALIMIN, SUGENG PURNOMO, RATIKO \\ Pusat Teknologi Limbah Radioaktif, BATAN, \\ Kawasan PUSPIPTEK Gd.50 Serpong Tangerang, 15310
}

\begin{abstract}
Abstrak
PROSES OKSIDASI BIOKIMIA UNTUK PENGOLAHAN LIMBAH SIMULASI CAIR ORGANIK RADIOAKTIF. Kegiatan industri nuklir menimbulkan limbah cair organik seperti limbah detergen dari pencucian pakaian kerja, pelarut 30\% TBP (tri-n-butyl phosphate) dalam kerosen dari pemurnian ataupun pengambilan uranium dari gagalan fabrikasi elemen bahan bakar, pelarut yang mengandung $\mathrm{D}_{2}$ EHPA (di-2-ethyl hexyl phosphoric acid) dan TOPO (trioctyl phospine oxide) dalam kerosin dari pemurnian asam fosfat. Limbah tersebut bersifat bahan berbahaya dan beracun (B-3) serta radioaktif, oleh karena itu limbah tersebut harus diolah sehingga terjadi detoksifikasi B-3 dan dekontaminasi radionuklidanya. Telah dilakukan penelitian proses oksidasi biokimia pengolahan limbah simulasi cair organik radioaktif dari pencucian pakaian kerja menggunakan campuran bakteri mutan aerob bacillus sp, pseudomonas $\mathrm{sp}$, arthrobacter $\mathrm{sp}$, dan aeromonas sp. Limbah berkadar deterjen $1,496 \mathrm{~g} / \mathrm{L}$, aktivitas $10^{-1} \mathrm{Ci} / \mathrm{m}^{3}$, dengan COD (Chemical Oxygen Demand) 128, BOD (Biological Oxygen Demand) 68 dan TSS (Total Suspended Solid) $1000 \mathrm{ppm}$, diolah dengan oksidasi biokimia dengan penambahan bakteri yang diberi nutrisi nitrogen dan fosfor, dan diaerasi. Hasilnya menunjukkan bahwa bakteri mampu menguraikan detergen menjadi karbon dioksida dan air sehingga memenuhi baku mutu air golongan B dengan kadar BOD dan COD berturut-turut berharga 6 dan $10 \mathrm{ppm}$, diperlukan waktu penguraian 106 jam untuk pemenuhan baku mutu tersebut. Semakin lama waktu proses memberikan kadar padatan total dalam lumpur semakin besar karena biomassa yang terbentuk dari massa koloni bakteri yang hidup dan mati semakin banyak.
\end{abstract}

Kata kunci : oksidasi biokimia, limbah radioaktif, limbah cair organik radioaktif

\begin{abstract}
BIOCHEMISTRY OXYDATION PROCESS FOR TREATMENT THE SIMULATION OF ORGANIC LIQUID RADIOACTIVE WASTE. The nuclear industry activities generate the organic liquid wastes such as detergent waste from laundry, solvent waste of 30\% TBP (tri-n-butyl phosphate) in kerosene from purification or recovery of uranium from rejection of nuclear fuel element fabrication, and solvent waste containing $\mathrm{D}_{2} \mathrm{EHPA}$ (di-2-ethyl hexyl phosphoric acid) and TOPO (trioctyl phospine oxide) in kerosene from phosphoric acid purification. The wastes are included in catagory of the hazard and poison materials which also
\end{abstract}


radioactive, so that the wastes have to be treated to detoxification of the hazard and poison materials and decontamination of the radionuclides. The research of biochemistry oxydation process for treatment the simulation of organic liquid radioactive waste from laundry using mixture of aerob bactery of bacillus sp, pseudomonas $\mathrm{sp}$, arthrobacter $\mathrm{sp}$, and aeromonas sp have been carried out. The waste containing detergent $1,496 \mathrm{~g} /$ Litre, activity $10^{-1} \mathrm{Ci} / \mathrm{m}^{3}$, with COD (Chemical Oxygen Demand) 128, BOD (Biological Oxygen Demand) 68 and TSS (Total Suspended Solid) $1000 \mathrm{ppm}$, it is treated by biochemistry oxydation with addition of bactery which be fed nutrision of nitrogen and phosphor, and aerasion. The result show that the bachtery can decompose the detergent to become carbon dioxyde and water so that can fulfill the quality standard of water group-B with content of BOD and COD are 6 and 10 ppm respectively, the time of decomposition is needed 106 hours to be fulfill the quality standard of water. The longer of process time will give bigger the total solid content in sludge, becouse the biomassa generated from the colony of bactery which life and dead to so much.

Keywords : biochemistry oxydation, radioactive waste, organic liquid radioactive waste

\section{PENDAHULUAN}

Kegiatan industri nuklir menimbulkan limbah cair organik radioaktif seperti limbah detergen persil dari pencucian pakaian kerja radiasi, limbah pelarut (solven) organik 30\% TBP (tri-n-butyl phosphate) dalam kerosin dari pemurnian atau pengambilan uranium dari gagalan fabrikasi bahan bakar nuklir, limbah pelarut yang mengandung $\mathrm{D}_{2} \mathrm{EHPA}$ (di-2-ethyl hexyl phosphoric acid) dan TOPO (trioctyl phospine oxide) dalam kerosin dari pemurnian asam fosfat. Detergen persil adalah jenis detergen berkadar buih rendah, merupakan senyawa alkyl-aril sulfonat yang mempunyai rumus $\mathrm{CH}_{3^{-}}$ $\left(\mathrm{CH}_{2}\right)_{10}-\mathrm{CH}_{2}-\mathrm{OSO}_{3} \mathrm{Na}$ atau $\mathrm{Na}^{+} \mathrm{R}^{+} \mathrm{SO}^{3-}$. Tiap molekul detergen dapat dianggap sebagai suatu rantai yang salah saatu ujungnya bersifat suka air (hidrofil) dan ujung lainnya bersifat takut air (hidrofob). Gugus $\mathrm{SO}^{3-}$ bersifat hidrofil dan rantai karbon $\mathrm{R}^{+}$bersifat hidrofob. Kotoran yang berupa lemak atau minyak menarik gugus hidrofob, sedangkan gugus hidrofil tertarik oleh air. Dari operasi pencucian pakaian kerja radiasi yang dilakukan di Instalasi Pengolahan Limbah Radioaktif-Pusat Teknologi Limbah Radioaktif (IPLRPTLR) ditimbulkan 133, $7 \mathrm{~m}^{3}$ limbah cair per tahun yang mengandung detergen konsentrasi maksimum 1,496 g/L dengan nilai COD (Chemical Oxygen Demand) 338 ppm, BOD (Biological Oxygen Demand) 189 ppm dan aktivitas minimal $10^{-6} \mathrm{C} / \mathrm{m}^{3}$. Limbah tersebut kemudian dicampur dengan limbah cair lain yang sejenis sehingga kadar detergen sangat rendah, kemudian diolah melalui proses evaporasi dilanjutkan dengan proses sementasi konsentrat hasil evaporasi. Unsur radioaktif utama dalam limbah adalah Cs-137 yang berwaktu paruh 30 tahun. Evaporasi limbah detergen 
tersebut menimbulkan buih, sehingga untuk mencegah distilat terkontaminasi unsur radioaktif dibutuhkan bahan anti buih. Biaya operasi evaporasi mahal karenaa diperlukan uap air pemanas yang dibangkitkan dari pembakaran minyak dalam boiler dan memerlukan bahan anti buih dan asam nitrat penghilang kerak $^{[1]}$.

TBP adalah senyawa organik yang mempunyai rumus $\mathrm{C}_{12} \mathrm{H}_{27} \mathrm{PO}_{4}$, merupakan pelarut pengekstraksi uranium dari senyawa uranil nitrat $\left[\mathrm{UO}_{2}\left(\mathrm{NO}_{3}\right)_{2}\right]$ yang mempunyai koefisien distribusi dan selektivitas tinggi, tahan radiasi, dan tahan asam. Dalam pemakaiannya TBP dilarutkan dalam kerosin odorless (tidak berbau) pada komposissi TBP dan kerosin masingmasing $30 \%$ daan $70 \%$ volume. Kerosin adalah senyawa hidrokarbon yang mempunyai jumlah atom $\mathrm{C}$ tiap molekulnya pada harga $\mathrm{C}_{9}$ sampai dengan $\mathrm{C}_{14}$, yang tersusun dari senyawa-senyawa alkana $\left(\mathrm{C}_{\mathrm{n}} \mathrm{H}_{2 \mathrm{n}+2}\right)$, siklo alkana (metal siklo pentana, etil siklo heksana, dan lain-lain), hidrokarbon aromatik (benzen, toluen dan lain-lain) yang mengandung nitrogen, belerang, oksigen dan organo logam ${ }^{[2]}$. Kerosin odorless (tidak berbau) adalah kerosin $99 \%$ yang mempunyai berat jenis $820 \mathrm{~kg} / \mathrm{m}^{3}$ dan viskositas $0,3 \mathrm{cp}$, komponen utamanya adalah senyawa alkana, kadar senyawa aromatiknya sangat rendah. Pelarut TBP-kerosin mempunyai nilai kalori pembakaran $10.000 \mathrm{kkal} / \mathrm{kg}$, limbah pelarut tersebut diolah dengan insenerasi. Pada pembakaran TBPkerosin timbul uap fosfat dalam gas hasil pembakaran yang merusak filter kantong (bag filter) dari inseneratorya. Untuk menghindari hal tersebut dilakukan penambahan garam kalsium formiat guna mengendapkan fosfat dalam bentuk kalsium fosfat yang kemudian terikat dalam abu pembakaran. Jadi pengolahan limbah TBP-kerosin memerlukan biaya operasi yang tinggi dan menimbulkan resiko kerusakan bag filter yang merupakan bagian penting dari treaatment gas hasil pembakaran.

$\mathrm{D}_{2}$ EHPA adalah senyawa organik yang mempunyai rumus $\mathrm{C}_{16} \mathrm{H}_{35} \mathrm{PO}_{4}$ mempunyai densitas $960 \mathrm{~kg} / \mathrm{m}^{3}$, nilai keasaman $171 \mathrm{mg} \mathrm{KOH} / \mathrm{g}$ dan viskositas 40 m.Pa.dt, bila terkena mata dan kulit menyebabkan iritasi dan bila terhisap pernafasan menyebabkan keracunan. TOPO merupakan senyawa organik dengan rumus $\mathrm{C}_{24} \mathrm{H}_{51} \mathrm{PO}$ mengandung $\mathrm{H}_{3} \mathrm{PO}_{4}$ kadar $0,2 \%$, mempunyai densitas $880 \mathrm{~kg} / \mathrm{m}^{3}$, titik didih $213{ }^{\circ} \mathrm{C}$, bila terkena mata dan kulit menyebabkan iritasi, dan bila terhisap pernafasan menyebabkan keracunan. Campuran pelarut organik yang digunakan dalam proses pemurnian uranium mempunyai rasio $\mathrm{D}_{2} \mathrm{EHPA}$, TOPO dan kerosin berturut-turut 4:1:16. Limbah pelarut tersebut mempunyai $\mathrm{pH} 4$, COD dan BOD berturut-turut 26.000 dan $1820 \mathrm{ppm}$, aktivitas alfa dan beta berturut-turut $0,002 \mathrm{~Bq} /$ liter dan 0,01 $\mathrm{Bq} / \mathrm{liter}^{[3]}$. Pelarut tersebut mempunyai kalori pembakaran lebih besar 10.000 $\mathrm{kkal} / \mathrm{kg}$, oleh karena itu limbah tersebut dapat dibakar dalam insenerator. 
Masalah yang timbul sama seperti yang dijumpai pada pembakaran solven TBP-kerosen. Limbah organik tersebut merupakan limbah bahan beracun dan berbahaya (B3) sekaligus juga sebagai limbah radioaktif. Proses oksidasi biokimia adalah cara pengolahan yang efektif untuk detoksifikasi limbah B3 melalui penguraian senyawa organik menjadi karbon dioksida dan air oleh bakteri yang diaerasi dan diberi nutrisi. Secara bersamaan terjadi pula dekontaminasi zat radioaktif dari larutan melalui biosorpsi unsur radioaktif oleh bakteri. Hasilnya sludge atau lumpur yang radioaktif dan non B3, dan beningan yang non B3 dan bebas kontaminasi zat radioaktif.

Di PTLR pengolahan limbah tersebut belum dilakukan, oleh karena itu perlu dilakukan penelitian proses oksidasi biokimia pengolahan limbah organik. Telah dilakukan penelitian proses oksidas biokimia pengolahan limbah organik radioaktif untuk mengetahui kondisi operasi dan unjuk kerja yang optimal. Pada tahap awal penelitian dilakukan pengolahan limbah simulasi detergen dari pencucian pakaian kerja radiasi.

\section{TEORI}

\section{Prinsip Oksidasi Biokimia}

Bila zat organik dihilangkan dari larutan melalui pengolahan secara proses biologi menggunakan bakteri (sel) sebagai mikroorganisme, terjadi dua fenomena dasar sebagai berikut : oksigen dikonsumsi oleh bakteri untuk memperoleh energi, dan massa sel baru terbentuk. Kebutuhan oksigen tersebut dipenuhi melalui penggelembungan udara ke dalam larutan (proses aerasi). Mikroorganisme juga mengalami auto-oksidasi secara progresif dalam massa selularnya ${ }^{[4]}$.

Reaksi tersebut digambarkan melalui persamaan sebagai berikut : sel

Zat organik $+\mathrm{a}^{\prime} \mathrm{O}_{2}+\mathrm{N}+\mathrm{P} \rightarrow$ a Sel baru $+\mathrm{CO}_{2}+\mathrm{H}_{2} \mathrm{O}+$ Residu selular tahan urai

$\mathrm{Sel}+\mathrm{b}^{\prime} \mathrm{O}_{2} \rightarrow \mathrm{b} \mathrm{CO}_{2}+\mathrm{H}_{2} \mathrm{O}+\mathrm{N}+\mathrm{P}+$ Residu selular tahan urai

Perlu diperhatikan dalam perencanaan dan operasi fasilitas pengolahan secara biologi adalah jumlah oksigen dan nutrisi, dan jumlah lumpur biologi yang diperoleh. Lumpur biologi tersusun dari sel baru dan residu selular tahan urai. Logam berat dan unsur radioaktif dalam limbah akan terjerap pada lumpur biologi, sehingga terjadi dekontaminasi larutan.

Besaran k dalam Persamaan 1 adalah konstante kecepatan reaksi yang merupakan fungsi kemampuan biodegradasi zat organik dalam limbah cair. Koefisien a' adalah fraksi zat organik yang dihilangkan melalui oksidasi menjadi hasil akhir berupa energi, dan koefisien a adalah fraksi zat organik yang dihilangkan melalui pengubahan menjadi massa sel. Koefisien b adalah 
fraksi biomassa yang dapat terdegradasi melalui oksidasi per hari dan b' adalah oksigen yang dibutuhkan untuk oksidasi tersebut.

Bakteri yang digunakan harus dapat menyesuaikan dengan media air limbah yang diolah. Untuk air limbah yang lebih kompleks, penyesuaian media tersebut dapat memakan waktu sampai 6 minggu. COD didifinisikan sebagai jumlah oksigen yang dibutuhkan untuk penguraian bahan organik melalui oksidasi kimia, sedangkan BOD didifinisikan sebagai jumlah oksigen yang dibutuhkan untuk penguraian bahan organik melalui oksidasi biokimia. Penghilangan BOD dari air limbah melalui lumpur biologi terjadi melalui 2 tahapan yaitu diawali penghilangan secara cepat zat tersuspensi, koloid dan BOD terlarut, diikuti dengan penghilangan lambat sisa BOD terlarut secara progresif.

Penghilangan BOD awal diselesaikan melalui satu atau lebih mekanisme berikut tergantung pada karakteristik fisika dan kimia dari zat organik $^{[4]}$ :

2. Penghilangan bahan tersuspensi termasuk logam berat dan unsur radioaktif melalui penangkapan dengan penjerapan pada flok biologi. Penghilangan ini berlangsung cepat dan tergantung pada tingkat pencampuran antara air limbah dan lumpur.

3. Penghilangan bahan koloid melalui penjerapan fisika kimia pada flok.

4. Penjerapan biologi zat organik terlarut oleh mikroorganisme, mungkin melalui pembentukan enzim oleh mikro-organisme, penarikan zat organik pada permukaan dinding bakteri atau sampai ke dalam sel.

Penghilangan BOD terlarut berbanding langsung dengan konsentrasi lumpur yang ada, umur lumpur, dan karakteristik kimia zat organik terlarut. Tipe lumpur yang dihasilkan sangat mempengaruhi sifat penjerapan. Pada umumnya lumpur dari operasi batch atau plug-flow mempunyai sifat penjerapan yang lebih baik daripada yang didapatkan dari operasi pencampuran sempurna.

\section{Proses Lumpur Aktif (Activated Sludge)}

Proses lumpur aktif adalah salah satu proses yang paling banyak dipakai untuk pengolahan air limbah secara biologis. Di dalam sistem ini bakteri disuspensikan untuk terus bergerak dan tidak mengendap melalui adukan, arus resirkulasi, atau gerakan lain yang ditimbulkan oleh aerator ${ }^{[4,5,6,7]}$. Dengan demikian lumpur aktif merupakan bahan yang mengandung populasi bakteri aktif yang digunakan dalam pengolahan air limbah. Pada proses kontinyu, lumpur aktif yang terbawa bersama air limbah hasil pengolahan dipisahkan dalam tangki pengenap dan sebagian lumpur aktifnya disirkulasikan kembali ke tangki aerasi, sedangkan bagian lainnya diambil 
sebagai hasil pekatan. Beningan yang dihasilkan proses lumpur aktif relatif jernih dan memenuhi syarat untuk dibuang.
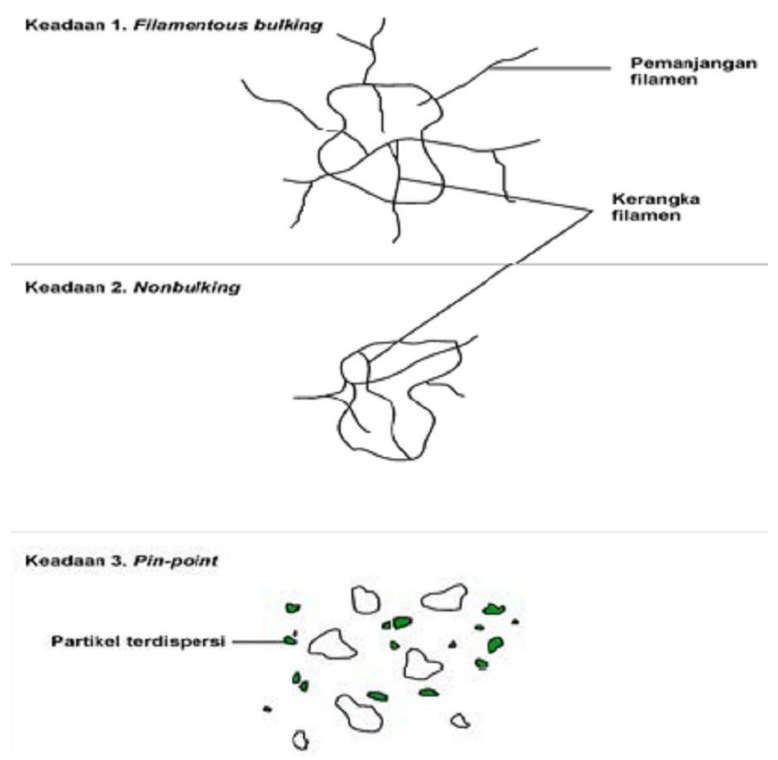

Gambar 1. Tipe-Tipe Lumpur Aktif

Salah satu faktor penting untuk unjuk kerja proses lumpur aktif adalahdan pemampatan yang cepat. McKinney menghubungkan flokulasi dengan rasio makanan,

(F) terhadap mikroorganisme (M) atau nilai F/M dan menunjukkan bahwa mikroorganisme (bakteri) secara normal ada di dalam lumpur aktif yang menggumpal dengan cepat pada kondisi kelaparan ${ }^{[4]}$. Lebih lanjut telah ditunjukkan bahwa flokulasi diakibatkan oleh pembentukan lapisan lumpur polisakarida yang lengket dimana mikroorganisme menempel. Flagela juga terjerat dalam bahan lumpur tersebut. Organisme bentuk filamen terdapat di dalam kebanyakan lumpur aktif kecuali pada limbah dari industri kimia dan petrokimia. Palm, dkk telah mengidentifikasi tiga macam lumpur aktif yaitu filamentous bulking, non-bulking, dan pin-point seperti yang ditunjukkan pada Gambar $1^{[4,7]}$. Lumpur non-bulking dihasilkan dari operasi plug-flow atau selector plant configuration, atau dari air limbah organik yang kompleks. Lumpur pin-point dihasilkan dari operasi dengan nisbah F/M yang rendah pada umur lumpur yang lama. Lumpur aktif jenis filamentous bulking yang mudah menyebabkan tersumbatnya sistem resirkulasi lumpur dan peralatan aerasi, dihasilkan dari air limbah yang mengandung glukosa, sakarosa, laktosa dan bahan sejenis. Kekurangan oksigen terlarut dalam air limbah di sistem pengolahan biologis menyebabkan terbentuknya lumpur 
filamentous bulking, pada konsentrasi oksigen kurang dari $0,1 \mathrm{mg} / \mathrm{l}$ terbentuklah filamen tipis 1-4 $\mu \mathrm{m}$. Untuk proses pengolahan secara biologis aerob yang bagus, hubungan antara konsentrasi oksigen terlarut dalam limbah dan nisbah F/M

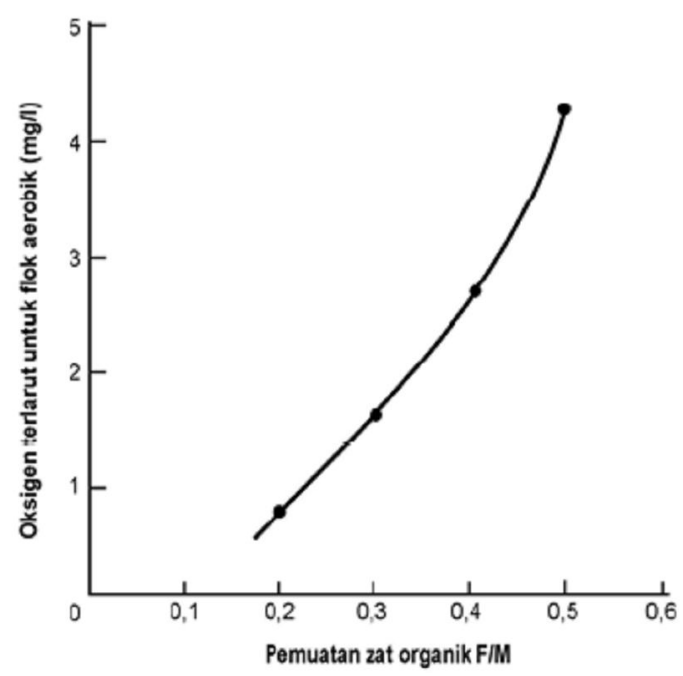

Gambar 2. Hubungan Oksigen Terlarut dengan Rasio F/M pada Flok Aerobik Dikembangkan oleh Palm, dkk (1980) seperti ditunjukkan pada Gambar $2^{[4]}$. Chudoba, dkk (1985) menunjukkan bahwa kecepatan pertumbuhan organisme sangat dipengaruhi oleh konsentrasi bahan organik dan rasio $\mathrm{F} / \mathrm{M}^{[8]}$. Pada bahan terdegradasi konsentrasi rendah, pertumbuhan lumpur cenderung berbentuk filamen. Hal ini menjelaskan mengapa pada sistem campuran dengan konsentrasi bahan organik rendah cenderung memberikan pertumbuhan lumpur bentuk filamen. Pada konsentrasi bahan organik yang tinggi, flok yang terbentuk menarik bahan organik dari larutan pada kecepatan yang tinggi dibanding dengan penarikan filamen, penarikan bahan organik oleh flok tersebut mendominasi proses yang terjadi. Oleh karena itu untuk memperoleh gradien konsentrasi bahan organik yang tinggi digunakan sistem operasi pengolahan biologis secara plug-flow, pemakaian selector atau contactor $^{[4,7]}$.

\section{Kontrol Pencemaran Logam Berat Oleh Mikroba}

Mikroorganisme dapat mengakumulasi logam berat dan unsur radioaktif dari lingkungan eksternalnya ${ }^{[4,5,6,7]}$. Jumlah zat yang terakumulasi bervariasi, mekanisme akumulasinya dapat terjadi melalui proses fisika, kimia, biologi, termasuk adsorpsi, presipitasi, pembentukan kompleks dan fenomena transfer massa. Sel yang hidup dan mati yang dihasilkan sel mikroba seperti penyusun 
dinding sel, pigmen, polisakarida, logam yang berikatan dengan protein, dan residu selular tahan urai, mampu menghilangkan logam dan unsur radioaktif dari larutan. Beberapa contoh akumulasi logam berat dan unsur radioaktif oleh mikroba ditunjukkan pada Tabel 1.

Tabel 1. Contoh Akumulasi Logam Berat dan Unsur Radioaktif oleh Mikroba ${ }^{[4]}$.

\begin{tabular}{|c|c|c|}
\hline Organisme & Unsur & $\begin{array}{c}\text { Uptake } \\
\text { (\% bobot kering) }\end{array}$ \\
\hline \multicolumn{3}{|l|}{ 1.Bakteri } \\
\hline Streptococcus sp. & $\mathrm{U}$ & $2-14$ \\
\hline S. viridochromogenes & $\mathrm{U}$ & 30 \\
\hline Thiobacillus ferrooxidans & $\mathrm{Ag}$ & 25 \\
\hline \multirow[t]{4}{*}{ Zooglea sp. } & $\mathrm{Cd}$ & $4-9$ \\
\hline & $\mathrm{Cu}$ & 34 \\
\hline & $\mathrm{Ni}$ & 13 \\
\hline & $\mathrm{U}$ & 44 \\
\hline \multirow[t]{3}{*}{ Citrobacter sp. } & $\mathrm{Pb}$ & $34-40$ \\
\hline & $\mathrm{Cd}$ & 40 \\
\hline & $\mathrm{U}$ & 90 \\
\hline Pseudomonas aeruginosa & $\mathrm{U}$ & 15 \\
\hline Kultur campuran & $\mathrm{Cu}$ & 30 \\
\hline Kultur campuran & $\mathrm{Ag}$ & 32 \\
\hline \multirow[t]{5}{*}{ Bacillus sp. } & $\mathrm{Pb}$ & 60,1 \\
\hline & $\mathrm{Cu}$ & 15,2 \\
\hline & $\mathrm{Zn}$ & 13,7 \\
\hline & $\mathrm{Cd}$ & 21,4 \\
\hline & $\mathrm{Ag}$ & 8,6 \\
\hline \multicolumn{3}{|l|}{ 2.Ganggang } \\
\hline Chlorella vulgaris & $\mathrm{Au}$ & 10 \\
\hline Chlorella regularis & $\mathrm{U}$ & 15 \\
\hline \multirow[t]{2}{*}{ C. regularis } & $\mathrm{U}$ & 0,4 \\
\hline & $\mathrm{Mn}$ & 0,8 \\
\hline \multicolumn{3}{|l|}{ 3.Jamur } \\
\hline Phoma sp. & $\mathrm{Ag}$ & 2 \\
\hline Penicillium sp. & $\mathrm{U}$ & $8-17$ \\
\hline \multirow{7}{*}{ Rhizopus arrhizus } & $\mathrm{Cu}$ & 1,6 \\
\hline & $\mathrm{Cd}$ & 3 \\
\hline & $\mathrm{Pb}$ & 10,4 \\
\hline & $\mathrm{U}$ & 19,5 \\
\hline & Th & $11,6-18,5$ \\
\hline & $\mathrm{Ag}$ & 5,4 \\
\hline & $\mathrm{Hg}$ & 5,6 \\
\hline \multirow[t]{2}{*}{ Aspergillus niger } & Th & 18,5 \\
\hline & $\mathrm{U}$ & 21,5 \\
\hline 4.Ragi & & \\
\hline \multirow{3}{*}{ Saccharomyces cereviseae } & $\mathrm{U}$ & $10-15$ \\
\hline & Th & 12 \\
\hline & $\mathrm{Zn}$ & 0,5 \\
\hline Ragi (14 strains) & $\mathrm{Ag}$ & $0,05-1$ \\
\hline
\end{tabular}


Penghilangan logam berat dan unsur radioaktif dari larutan dengan bahan biologi, khususnya melalui interaksi yang tidak langsung secara fisikakimia biasa disebut bioabsorpsi. Pada dasarnya semua bahan biologi mempunyai sifat bioabsorpsi, tidak hanya mikroba saja yang memiliki sifat tersebut. Bioabsorpsi dan fenomena yang terkait merupakan proses yang penting karena penghilangan racun kuat, logam berat, dan unsur radioaktif dari limbah cair dapat menghasilkan detoksifikasi larutan, sehingga pelepasan buangan cair ke lingkungan dapat berlangsung secara $\operatorname{aman}{ }^{[4,5,6,7]}$.

\section{Kebutuhan Nutrisi Pada Proses Oksidasi Biokimia}

Beberapa unsur mineral sangat diperlukan sebagai nutrisi untuk metabolisme zat organik oleh mikroorganisme, kecuali nitrogen dan fosfor mineral tersebut biasanya telah ada dalam jumlah yang cukup dalam air. Nutrisi yang kebutuhannya sedikit untuk oksidasi biokimia diberikan pada Tabel $2^{[4]}$. Kotoran dalam air limbah memberikan kesetimbangan makanan mikroba, tetapi banyak air limbah industri (gula, kertas, pulp, dan lain-lain) tidak mengandung cukup nitrogen dan fosfor, dan memerlukan penambahan sebagai suplemen nutrisi.

Kuantitas nitrogen dan fosfor yang diperlukan untuk penghilangan BOD yang efektif dan terjadinya sintesis mikroba telah diteliti oleh Melmer, et.al 1951, sebesar 4,3 kgN/100 kg BOD dan 0,6 kg P/100 kg BOD, yang diturunkan dari beberapa pengolahan air limbah industri yang memerlukan nutrisi nitrogen dan fosfor. Di dalam prakteknya nutrisi diberikan pada kuantitas BOD $: \mathrm{N}: \mathrm{P}=100: 5: 1^{[4,5,6]}$.

Tidak semua senyawa nitrogen organik dapat untuk sintesis mikroba. Nitrogen biasanya ditambahkan dalam bentuk urea, senyawa nitrogen sebelum digunakan harus dikonversi lebih dahulu ke bentuk amonia, nitrit, nitrat dan sekitar $75 \%$ senyawa nitrogen organik juga dapat digunakan untuk sintesis mikroba, fosfor dapat diberikan sebagai asam fosfat, tri super phosphate (TSP) biasanya digunakan sebagai sumber nutrisi fosfor. Tabel 2 menunjukkan nutrisi yang dibutuhkan untuk oksidasi biokimia.

Dalam percobaan yang dilakukan digunakan nutrisi urea sebagai sumber $\mathrm{N}$ dan TSP sebagai sumber $\mathrm{P}$, dengan pebandingan BOD : N:P = 100 :5:1. 
Tabel 2. Nutrisi yang Dibutuhkan untuk Oksidasi Biokimia dalam Jumlah yang Kecil (Bentuk Ion) ${ }^{[4]}$

\begin{tabular}{ccc}
\hline No & $\begin{array}{c}\text { Jenis Nutrisi } \\
\text { (ion unsur) }\end{array}$ & $\begin{array}{c}\text { Kadar } \\
\text { (mg/mg BOD) }\end{array}$ \\
\hline 1 & $\mathrm{Mn}$ & $10 \times 10-5$ \\
2 & $\mathrm{Cu}$ & $14,6 \times 10-5$ \\
3 & $\mathrm{Zn}$ & $16 \times 10-5$ \\
4 & $\mathrm{Mo}$ & $43 \times 10-5$ \\
5 & $\mathrm{Se}$ & $14 \times 10-10$ \\
6 & $\mathrm{Mg}$ & $30 \times 10-4$ \\
7 & $\mathrm{Co}$ & $13 \times 10-5$ \\
8 & $\mathrm{Ca}$ & $62 \times 10-4$ \\
9 & $\mathrm{Na}$ & $5 \times 10-5$ \\
10 & $\mathrm{~K}$ & $45 \times 10-4$ \\
11 & $\mathrm{Fe}$ & $12 \times 10-3$ \\
12 & $\mathrm{CO} 3$ & $27 \times 10-4$ \\
\hline
\end{tabular}

\section{Pengaruh Suhu Pada Proses Oksidasi Biokimia}

Varisasi suhu sangat berpengaruh pada hasil pengolahan secara proses biologi. Ada 3 macam daerah suhu yaitu mesophilic dengan daerah suhu 4-39 ${ }^{\circ} \mathrm{C}$, thermophilic dengan daerah suhu $55^{\circ} \mathrm{C}$, dan psychrophilic dengan daerah operasi suhu lebih kecil dari $4^{\circ} \mathrm{C}$. Untuk pertimbangan ekonomis dan alasan geografis, kebanyakan proses pengolahan secara biologi aerobik dioperasikan pada daerah mesophilic, pada daerah tersebut kecepatan reaksi biologi akan bertambah dengan naiknya suhu sampai suhu maksimum $31{ }^{\circ} \mathrm{C}^{[4]}$.

Pada suhu di atas $35,5{ }^{\circ} \mathrm{C}$ terjadi penurunan jumlah flok biologi. Protozoa akan menghilang pada suhu $40{ }^{\circ} \mathrm{C}$ dan pada $43,3{ }^{\circ} \mathrm{C}$ flok menjadi rusak dan terdispersi kembali dalam larutan karena terjadinya penurunan kecepatan pengenapan yang tajam. Oleh karena itu direkomendasikan suhu makasimum kolom aerasi adalah $35,5{ }^{\circ} \mathrm{C}$. Penurunan suhu kolam aerasi menyebabkan kenaikan padatan tersuspensi dalam efluen. Dalam percobaan yang dilakukan dipilih suhu kamar.

\section{Pengaruh pH Pada Proses Oksidasi Biokimia}

Kebanyakan proses oksidasi biokimia mempunyai daerah $\mathrm{pH}$ efektif yang relatif sempit yaitu pada nilai 5-9 dengan kondisi optimum pada $\mathrm{pH} 6,5-8,5^{[4]}$. Nilai $\mathrm{pH}$ tersebut adalah $\mathrm{pH}$ dari campuran larutan dalam kontak dengan pertumbuhan biologi dan bukan $\mathrm{pH}$ larutan masuk. Larutan limbah terencerkan ketika masuk ke dalam tangki aerasi dan ternetralisisr oleh $\mathrm{CO}_{2}$ yang dihasilkan bakteri. Untuk limbah yang bersifat asam dan basa, hasil akhir adalah bikarbonat $\left(\mathrm{HCO}_{3}{ }^{-}\right)$yang merupakan laruan penyangga efektif untuk sistem aerasi pada $\mathrm{pH}$ tetap sekitar 8 . 


\section{Keracunan Sistem Oksidasi Biokimia}

Keracunan dalam sistem oksidasi biokimia dapat disebabkan oleh satu dari beberapa penyebab sebagai berikut:

1. Suatu zat organik seperti fenol, yang menimbulkan racun hanya pada konsentrasi tinggi tetapi dalam konsentrasi rendah terurai.

2. Logam berat yang menimbulkan racun pada suatu ambang konsentrasi tergantung pada kondisi operasi.

3. Garam anorganik dan amonia pada konsentrasi yang tinggi.

Pengaruh racun dari zat organik dapat diminimisasi dengan pencampuran yang sempurna sehingga larutan limbah terencerkan oleh larutan yang ada dalam tangki aerasi, dan mikroorganisme hanya dalam kontak dengan larutan. Logam berat pada konsentrasi rendah menimbulkan keracunan lumpur biologi, penyesuaian lumpur terhadap logam berat akan menaikkan nilai ambang keracunan tersebut. Logam berat akan dipekatkan dalam lumpur sebagai senyawa kompleks pada dinding permukaan bakteri sampai kadar $4 \%$ fraksi berat ${ }^{[4]}$.

\section{TATA KERJA}

\section{Bahan}

Bahan-bahan yang digunakan adalah bahan produksi E.Merck antara lain kalium dikarbonat, asam sulfat, perak sulfat, merkuri sulfat, fero amonium sulfat, mangan sulfat, natrium hidroksida, kalium iodida, natrium tiosulfat, indikator amilum, serta kristal sesium nitrat. Nutrisi yang digunakan urea dan TSP (tri-super phosphate). Deterjen persil yang digunakan produksi PT.Estrela laboratories, Bogor, di bawah lisensi Henkel KGaA, Jerman. Bakteri yang digunakan adalah bakteri SGB produksi PT. Nusantara Water Center, Jakarta, jenis super growth bacteria (SGB), yang merupakan campuran dari bakteri Bacillus sp, Psedudomonas sp, Arthrobacter sp, dan Aeromonas sp, terdiri dari SGB 103 yang mengandung 10,4 juta bakteri/ml dan berdensitas 0,996 g/Liter.

\section{Peralatan}

Peralatan yang digunakan adalah unit proses biooksidasi pengolahan limbah deterjen (Unit proses tersebut ditunjukkan pada Gambar 3). Untuk pengukuran $\mathrm{pH}$ dan kadar oksigen terlarut digunakan alat Water Checker. Untuk pengukuran BOD dan COD digunakan alat Spektrofotometer $U V$-VIS, sedang untuk pengukuran konsentrasi cesium digunakan alat Spektrofotometer Serapan atom $(A A S)$. 


\section{Metode}

Pembuatan Limbah Simulasi

Cesium nitrat $0,12 \mathrm{mg}$ dilarutkan dalam 0,5 liter air sehingga diperoleh larutan aktivitas $\mathrm{Cs}-137$ sebesar $10 \mathrm{Ci} / \mathrm{m}^{3}$. Larutan tersebut dipakai sebagai larutan induk untuk pembuatan larutan limbah aktivitas $10^{-3} \mathrm{Ci} / \mathrm{m}^{3}$ melalui pengenceran. Deterjen persil $74,8 \mathrm{~g}$ ditimbang dan dilarutkan ke dalam 50 liter larutan $10^{-3} \mathrm{Ci} / \mathrm{m}^{3}$, diperoleh larutan berkadar deterjen 1,496 $\mathrm{g} / \mathrm{Liter}$ dengan aktivitas $10^{-3} \mathrm{Ci} / \mathrm{m}^{3}$.

\section{Pengolahan Limbah Secara Biooksidasi}

Limbah cair silmulasi yang ekivalen aktivitasnya $10^{-3} \mathrm{Ci} / \mathrm{m}^{3}$ mengandung deterjen pada konsentrasi 1,496 g/Liter dimasukkan ke dalam reaktor yang telah terpasang pemipaannya (seperti ditunjukkan pada Gambar 3 ), sebanyak 120 liter ke bak aerasi R01 dan dan 50 liter ke bak pemisah lumpur R02. Pompa resirkulasi larutan P01 dan aerator P02, P03, dan P04 dijalankan dengan konfigurasi kran V06 tertutup, kran V04 dan V05 terbuka pada posisi persen pembukaan tertentu sehingga tinggi permukaan cairan pada R01 dan R02 menjadi tetap. Kemudian dimasukkan sejumlah nutrisi urea dan TSP pada perbandingan BOD : N: $\mathrm{P}=100: 5: 1$, pada suhu kamar. Pengukuran $\mathrm{pH}$ dan oksigen terlarut dalam larutan yang ada di reaktor dilakukan dengan alat Water Checker. Bakteri SGB 103 sebanyak 72 ml kemudian dimasukkan ke dalam reaktor.

Pompa dan aerator terus dijalankan, lumpur aktif tersirkulasikan. Larutan nutrisi urea dan TSP pada konsentrasi yang sama seperti pada reaktor R01 diisikan ke dalam tangki nutrisi T03, kran V03 dibuka sedemikian sehingga larutan menetes masuk ke bak aerasi R01 tetes demi tetes. Sampel larutan diambil setiap 2 jam sekali setelah bakteri menyesuaikan kondisi limbah deterjen tersebut. Analisis COD, total solid (padatan) dan konsentrasi cesium dalam larutan dilakukan.

\section{HASIL DAN PEMBAHASAN}

Air yang digunakan dalam pencucian pakaian kerja radiasi di Instalasi Pengolahan Limbah Radioaktif (IPLR) adalah air domestik dari Puspiptek yang berasal dari sungai Cisadane yang telah diolah. Untuk metabolisme oleh mikroorganisme, nutrisi yang perlu ditambah hanyalah nitrogen dan fosfor, karena nutrisi lainnya seperti yang ditunjukkan pada Tabel 1 dianggap telah ada dalam jumlah yang cukup. Nutrisi nitrogen dan fosfor diberikan pada nisbah BOD : $\mathrm{N}: \mathrm{P}=100: 5: 1^{[2,4,5]}$. Data jumlah bakteri SGB 103 dan 
nutrisi minimal untuk proses oksidasi biokimia limbah deterjen sebagai fungsi konsentrasi deterjen atau nilai BOD ditunjukkan pada Tabel 3.

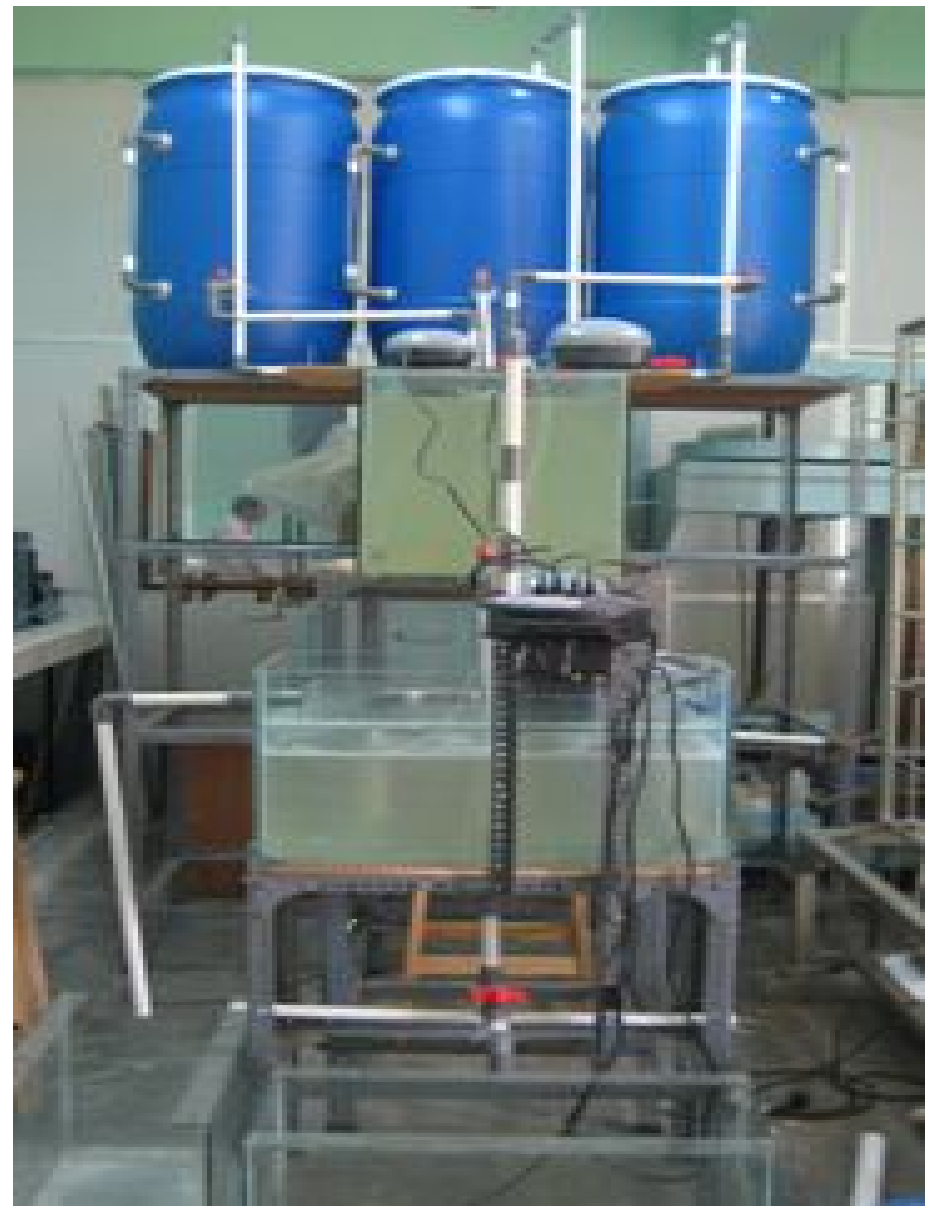

Gambar 3. Unit Proses Oksidasi Biokimia Pengolahan Limbah Deterjen Terpasang Hasil Rancangan.

Percobaan dilakukan pada suhu kamar, masuk pada daerah suhu mesophilic, kecepatan reaksi oksidasi biokimia mendekati harga maksimal pada suhu 31 ${ }^{\circ} \mathrm{C}$. Larutan limbah terencerkan oleh larutan yang ada di dalam tangki aerasi dan ternetralisisir oleh $\mathrm{CO}_{2}$ yang dihasilkan bakteri. Hasil akhir adalah bikarbonat yang merupakan penyangga efektif untuk sistem aerasi, sehingga $\mathrm{pH}$ larutan berharga tetap 8 .

Dari hasil pengukuran, nilai COD dan BOD larutan deterjen kadar 1,496 g/Liter berturut-turut adalah 338 dan $186 \mathrm{ppm}$. Semakin besar konsentrasi deterjen dalam larutan memberikan kenaikan nilai COD dan BOD karena kebutuhanoksigen untuk penguraian secara kimia dan secara 
biologi meningkat. Dari pengamatan percobaan diperoleh kondisi bahwa baktei SGB 103 dapat menyesuaikan kondisi limbah deterjen konsentrasi 1,496 g/Liter setelah waktu 96 jam, yaitu ditandai dengan mulai terjadinya reaksi sesuai dengan Persamaan 1 dan 2 ditandai mulai timbul massa lumpur coklat muda kehijauan. Setelah waktu penyesuaian tersebut contoh larutan diambil dari reaktor setiap 2 jam sekali untuk penentuan kadar COD, BOD, total padatan, dan konsentrasi Cesium-137.

Grafik hubungan COD terhadap waktu proses pada pengolahan limbah deterjen kadar 1,496 g/Liter menggunakan bakteri SGB 103 ditunjukkan pada Gambar 4, sedangkan grafik hubungan BOD terhadap waktunya ditunjukkan pada Gambar 5. Dari Gambar 4 tersebut terlihat bahwa nilai COD semakin menurun pada waktu proses yang semakin lama. Hal ini disebabkan oleh terjadinya peningkatan penguraian deterjensecara kimia dalam limbah, sehingga jumlah deterjen dalam larutan semakin turun.

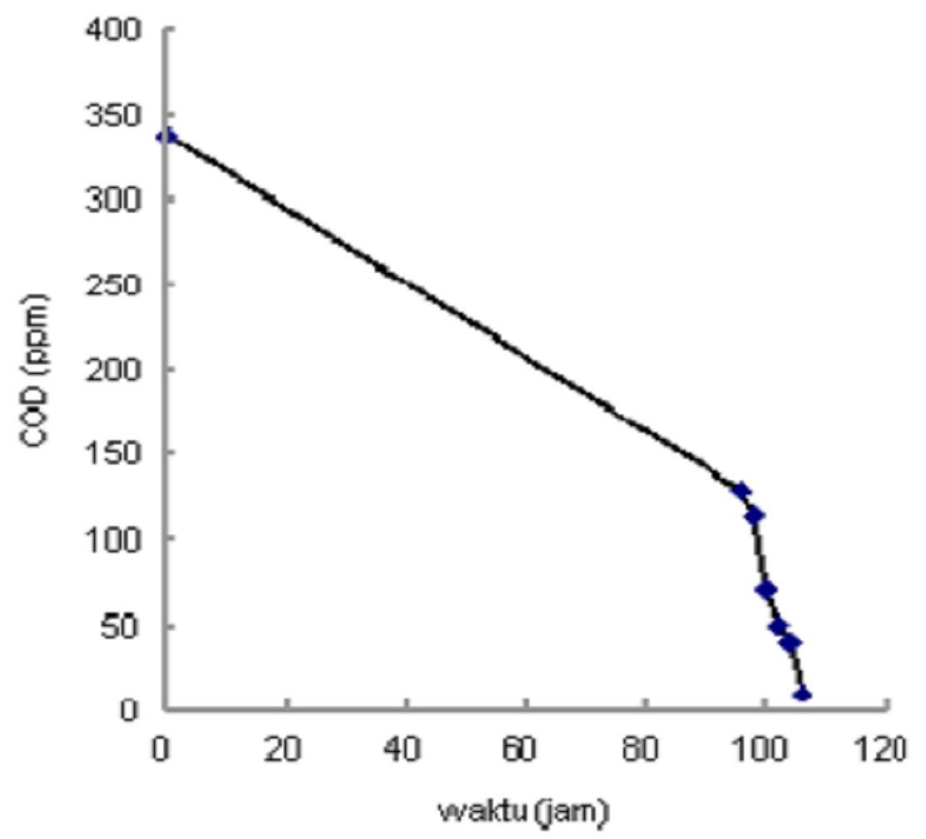

Gambar 4. Kurva Pengaruh Waktu Proses Terhadap Kadar COD Pada PengolahanLimbah Detergen Kadar 1,496 g/L dengan Bakteri SGB 103

Bakteri SGB 103 mampu menguraikan detergen sampai nilai baku mutu air buangan golongan B dengan COD 10 ppm, diperlukan waktu 106 jam untuk penguraian tersebut. Hal yang sama terjadi dengan semakin lama waktu proses memberikan penurunan nilai BOD (Gambar 5). 


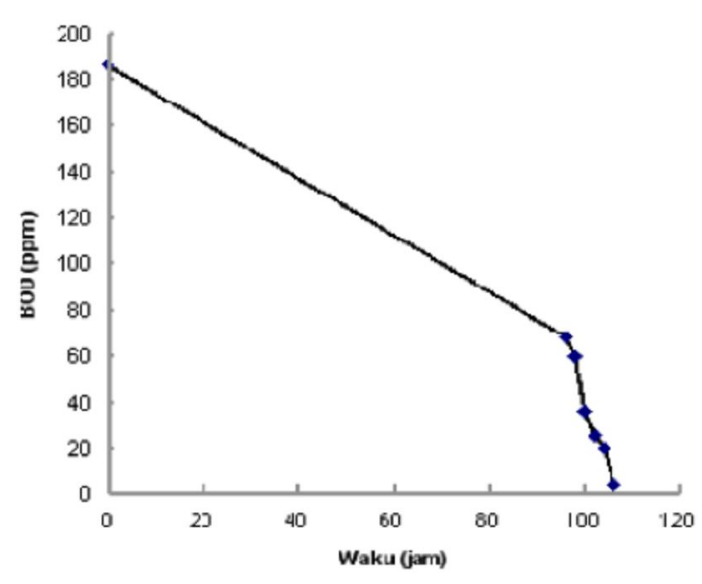

Gambar 5. Kurva Pengaruh Waktu Proses Terhadap Kadar BOD

Pada Pengolahan Limbah Detergen Kadar 1,496 g/L dengan Bakteri SGB 103

Dari hasil analisis larutan detergen kadar 1,496 g/L mempunyai kadar TSS (Total Suspended Solid) 1000 ppm. Gambar 6 menunjukkan hubungan waktu proses oksidasi biokimia terhadap kadar padatan total dalam lumpur untuk bakteri SGB 103. Terlihat bahwa padatan total semakin meningkat pada waktu proses yang semakin lama. Semakin lama waktu proses maka biomassa yangdihasilkan oleh sel mikroba semakin banyak sehingga kadar padatan total dalam lumpur semakin besar.

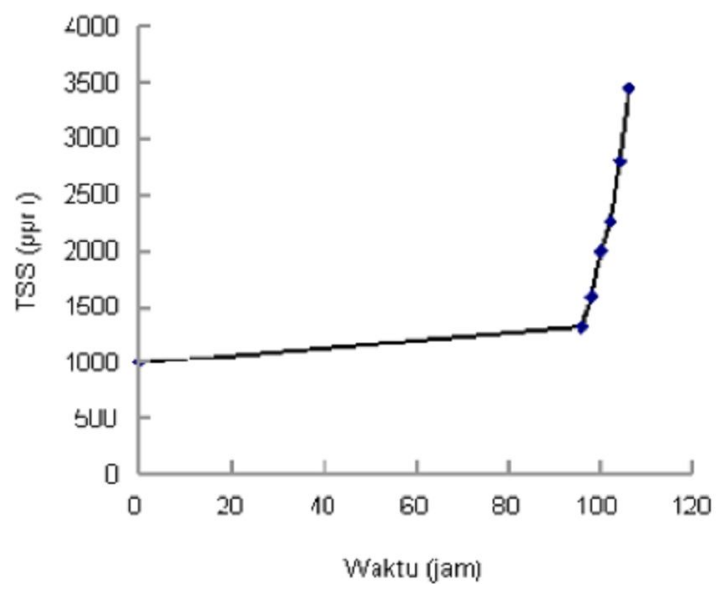

Gambar 6. Kurva Pengaruh Waktu Proses Terhadap Kadar Padatan Total Dalam Lumpur Pada Pengolahan Limbah Detergen Kadar 1,496 g/L Dengan Bakteri SGB 103 
Tabel 3. Data Jumlah SGB 103 dan Nutrisi Minimal untuk Proses Oksidasi Biokimia Limbah Deterjen.

\begin{tabular}{|c|c|c|c|c|c|c|c|c|}
\hline \multirow{3}{*}{$\begin{array}{l}\text { Kadar } \\
\text { Deterjen } \\
\text { (g/Liter) }\end{array}$} & \multirow{3}{*}{$\begin{array}{l}\text { BOD } \\
(\mathrm{ppm})\end{array}$} & \multirow{3}{*}{$\begin{array}{c}\mathrm{DO} \\
(\mathrm{ppm})\end{array}$} & \multirow{3}{*}{$\mathrm{F} / \mathrm{M}$} & \multirow{3}{*}{$\begin{array}{c}\mathrm{M} / \rho \\
\text { (bakteri yang } \\
\text { ditambahkan) } \\
(\mathrm{ml})\end{array}$} & \multicolumn{4}{|c|}{$\begin{array}{l}\text { Jumlah Nutrisi Yang Ditambahkan } \\
\text { ke dalam larutan (mg) }\end{array}$} \\
\hline & & & & & \multicolumn{2}{|c|}{ Urea } & \multicolumn{2}{|c|}{ TSP } \\
\hline & & & & & $\begin{array}{l}\text { Per } \\
\text { liter }\end{array}$ & $\begin{array}{l}\text { Per } 170 \\
\text { liter }\end{array}$ & $\begin{array}{l}\text { Per } \\
\text { liter }\end{array}$ & $\begin{array}{l}\text { Per } 170 \\
\text { liter }\end{array}$ \\
\hline 1,496 & 185,90 & 5,4 & 0,51 & 72 & 200 & 3400 & 50 & 700 \\
\hline \multicolumn{9}{|c|}{$\begin{array}{l}\text { Catatan : } \\
\mathrm{F}=\text { BOD } x \text { Volume larutan total }(\mathrm{mg}) \text {. } \\
\mathrm{M}=\text { Jumlah larutan bakteri yang ditambahkan }(\mathrm{mg}) \text {. } \\
\rho=\text { Densitas larutan bakteri }=0,996 \mathrm{~g} / \mathrm{ml})\end{array}$} \\
\hline
\end{tabular}

\section{KESIMPULAN}

Hasil percobaan menunjukkan bahwa campuran bakteri mutan aerob bacillus $s p$, pseudomonas $s p$, arthrobacter sp dan aeromonas sp dalam SGB 103 mampu menyesuaikan kondisi limbah deterjen konsentrasi 1,496 g/Liter setelah waktu 96 jam dengan indikasi mulai timbul massa lumpur terdispersi dalam larutan yang berwarna coklat muda kehijauan. Proses lumpur aktif dengan bakteri SGB 103 pada tekanan 1 atmosfir, suhu kamar, pemberian aerasi pada nilai DO 5,4 ppm pemberian nutrisi pada nisbah BOD : $\mathrm{N}: \mathrm{P}=$ $100: 5: 1$ dapat memberikan hasil sebagai berikut : COD dan BOD dapat mencapai syarat baku tingkat buangan golongan $\mathrm{B}$ yang berkadar berturutturut 10 dan $6 \mathrm{ppm}$. Untuk memenuhi syarat baku mutu tersebut diperlukan waktu proses $106 \mathrm{jam}$. Semakin lama waktu proses memberikan kadar padatan total dalam lumpur semakin besar karena biomassa yang terbentuk dari massa koloni bakteri yang hidup dan mati semakin banyak.

\section{DAFTAR PUSTAKA}

1. SALIMIN Z, 1997, "Evaporasi Limbah Radioaktif Cair yang Mengandung Deterjen Dengan Anti Buih Minyak Silikon" (Prosiding pertemuan dan Presentasi Ilmiah Teknologi Pengolahan Limbah I, Serpong 10-11 Desember 1997), Pusat Teknologi Pengolahan Limbah Radioaktif, Badan Tenaga Nuklir Nasional, Jakarta.

2. PETRUCCI RALPH, H, 1985, General Chemistry, Principles and Modern Application, Four Edition, Collier Mr Millan, London.

3. SALIMIN Z, NANANG TS, ACHMAD ZAID, CHOTIMAH DAN KARYONO, 2008, "Dekomisioning Fasilitas Pemurnian Asam Fosfat Petrokimia Gresik", Prosiding Seminar Nasional Teknologi Limbah VI, 
PTLR BATAN, Jakarta 24 Juni 2008, Pusat Teknologi Limbah Radioaktif, Jakarta.

4. WESLEY, E, 1989, Industrial Water Pollution Control, Second Edition, Mc Graw-Hill Book Company, International Edition, Singapore.

5. HANEL, L.B.H, 1979, Biological Treatment of Sewage by Activated Sludge Process, Theory and Operation, 3th Ed, John Wiley \& Sons, New York.

6. McKINNEY RE., 1963, Advance in Biological Waste Treatment, New York: Perg. Pr.

7. PALM JC, et al., 1980, Three Generic Types of Activate Sludge, J. Water Polut. Control Feed. 52:484.

8. CHUDOBA J., 1985, Microbial Growth Caracteristic, Water Resources 18:47. 
